\title{
STUDIES ON THE MAIZE COLD TOLERANCE TESTS IN THE MARTONVÁSÁR PHYTOTRON
}

\author{
C. L. MARTON, C. SZÖKE and J. PINTÉR \\ AGRICULTURAL INSTITUTE, CENTRE FOR AGRICULTURAL RESEARCH, HUNGARIAN \\ ACADEMY OF SCIENCES MARTONVÁSÁR, HUNGARY
}

Received: ; accepted:

\begin{abstract}
The climatic conditions in Hungary and in the countries to which seed is exported makes the study of maize cold tolerance and constant improvements in the cold tolerance of Martonvásár hybrids especially important. An improvement in the early spring cold tolerance of maize would allow it to be grown in more northern areas with a cooler climate, while on traditional maize-growing areas the profitability of maize production could be improved by earlier sowing, leading to a reduction in transportation and drying costs and in diseases caused by Fusarium sp. The recognition of this fact led Martonvásár researchers to start investigating this subject nearly four decades ago. The phytotron has proved an excellent tool for studying and improving the cold tolerance of maize. The review will give a brief summary of the results achieved in the field of maize cold tolerance in the Martonvásár institute in recent decades.
\end{abstract}

Key words: maize, cold tolerance, phytotron, Fusarium

\section{Introduction}

Nowadays maize production is one of the most important branches of crop production, both in Hungary and on a world scale. Its importance is proved by the fact that in recent decades the sowing area has moved ever further north in Europe. On the whole, the ecological conditions in Hungary are favourable for maize production. In the major maize-producing regions of the country, the only suboptimal temperature effects during the vegetation period of maize occur in the germination and early development stages. Maize yield averages are substantially influenced by resistance to abiotic stress, including chilling in early spring. The phytotron has proved an excellent tool for studying and improving the cold tolerance of maize. Reproducible, identical environmental conditions (low temperature, damp soil) can be ensured during germination and emergence. In nature, cold, wet springs only occur every 4-7 years, so under natural conditions selection can only be conducted with low efficiency. 


\section{Materials and methods}

The aim was to study the cold tolerance of Martonvásár maize genotypes. The genotypes were examined in E-15 and G-30 phytotron cabinets and PGB-96 phytotron units (Tischner et al., 1997). The data were evaluated using analysis of variance (Sváb, 1981).

\section{Results and discussion}

The first cold tolerance tests in Martonvásár were set up using the cold test method elaborated by Clark (1954) relying on the results of Tatum and Zuber (1943) and Neptune (1953). These trials were conducted mainly to study the cold tolerance of the inbred lines used at the time, applying temperatures of $6-8^{\circ} \mathrm{C}$ for ten days, followed by $14-16^{\circ} \mathrm{C}$. The germination percentage was found to decrease even under sterile conditions as the length of the cold incubation increased (Kovács, 1961). Under field conditions the decrease in germinating ability was even greater due to the effect of pathogens (Table 1).

Herczegh (1970) recommended the use of a new climatic programme (10 days' incubation at $8^{\circ} \mathrm{C}$ followed by 20 days at $13.5^{\circ} \mathrm{C}$ ) which made it possible to distinguish more clearly between the chilling tolerance levels of the genotypes. It was recommended that genotypes should be characterised by the ratio of the maximum germination percentage and the corresponding germination time, i.e. by the cold tolerance index. Herczegh (1983) evaluated a large number of breeding stocks belonging to different related groups on the basis of the number of days to emergence (Table 2). Lines belonging to the Lancester (A) group emerged nearly three days later than those of the Reid Yellow Dent (B) group. Stocks of European origin were similar to those of the Reid Yellow Dent group. Hybrids between European lines and those of the Reid Yellow Dent group had better cold tolerance than hybrids of lines from groups A and $\mathrm{B}$. This is particularly important, because the yielding ability of these hybrids is also better than that of $\mathrm{A} \times \mathrm{B}$ hybrids.

When studying the cold tolerance of populations with different levels of heterozygosity it was found that the $0 \%$ (lines) and $100 \%\left(\mathrm{~F}_{1}\right.$ hybrids) heterozygotic forms had the lowest emergence percentage, whereas populations with a $50 \%$ rate of heterozygosity had the highest emergence percentage. The $50 \%$ and $100 \%$ heterozygotic forms had the shortest emergence time (Table 3 ). In the case of hybrids there was an increase in the germination percentage and a decrease in the time to emergence as the heterozygotic level of the female rose. An $r=-0.87$ to -0.90 correlation was found between the heterozygotic level of the female and the time to emergence, and $\mathrm{r}=0.73-0.89$ between the heterozygotic level of the female and the germination percentage of the hybrid (Szundy and Kovács, 1981a, b). 
Table 1

Effect of length of cold treatment and germination medium on the "cold test" germination percentage of inbred lines (Kovács, 1961)

\begin{tabular}{cccc}
\hline $\begin{array}{c}\text { Length of cold treatment } \\
\text { (days) }\end{array}$ & $\begin{array}{c}\text { Soil from maize } \\
\text { field }\end{array}$ & Germination medium sand & Sterilized sand \\
\hline 9 & 34.4 & 60.5 & 81.0 \\
12 & 24.2 & 52.5 & 74.2 \\
15 & 18.5 & 45.8 & 66.4 \\
18 & 15.9 & 39.5 & 59.1 \\
\hline
\end{tabular}

Table 2

Cold tolerance of breeding stocks belonging to various related groups (No. of days to emergence) (Herczegh, 1983)

\begin{tabular}{lccc}
\hline \multicolumn{1}{c}{ Breeding stocks } & "A" & "B" & European origin \\
& Lancaster & Reid Yellow Dent & \\
\hline Elite lines & 24.7 & 22.1 & 22.4 \\
Populations & 20.6 & 17.9 & 19.4 \\
\hline
\end{tabular}

Table 3

Cold tolerance of populations with different levels of heterozygosity (Szundy and Kovács, 1981a)

\begin{tabular}{lccccc}
\hline \multirow{2}{*}{\multicolumn{1}{c}{ Trait }} & \multicolumn{3}{c}{ Levels of heterozygosity } & \multirow{2}{*}{ LSD $_{5 \%}$} \\
\cline { 2 - 5 } & $0 \%$ & $25 \%$ & $50 \%$ & $100 \%$ & \\
\hline Days to emergence & 20.1 & 18.0 & 17.0 & 17.0 & 0.51 \\
Emergence (\%) percentage & 41.3 & 84.0 & 89.1 & 51.3 & 3.8 \\
\hline
\end{tabular}

From the study of the cold tolerance of $\mathrm{S}_{2}$ maize families it was concluded that there is sufficient variability for selection for improved cold tolerance both regarding the number of days to emergence and the emergence percentage (Quang and Szundy, 1989) (Table 4). A close, positive correlation was observed for the number of days to emergence between the $S_{1}$ and $S_{2}$ families. The correlation coefficient between the $S_{1}$ generation and the means of $S_{2}$ families originating from the same $S_{1}$ plant was $r=0.97$, significant at the $P=1 \%$ level. The correlation between the days to germination of the $S_{1}$ individuals and the $S_{2}$ families was also close $(\mathrm{r}=0.69)$ and significant at the $\mathrm{P}=1 \%$ level. The correlation between the numbers of $\mathrm{S}_{1}$ and $\mathrm{S}_{2}$ plants emerging from the cold soil was also close and significant. A close correlation $(r=0.99)$ significant at the $\mathrm{P}=0.1 \%$ level was observed between the germination percentages of the $\mathrm{S}_{1}$ generation and the means of $S_{2}$ families originating from the same $S_{1}$ plant. The correlation coefficient between the germination percentages of the $S_{1}$ individuals and $\mathrm{S}_{2}$ families $(\mathrm{r}=0.52)$, however, was only significant at the $\mathrm{P}=5 \%$ level. The results of the correlation studies revealed that the two most important indicators of cold tolerance investigated, the number of days to emergence and the germination percentage, were reliably inherited in the progeny generation. 
Table 4

Cold tolerance of $\mathrm{S}_{2}$ maize families (Quang and Szundy, 1989)

\begin{tabular}{lccc}
\hline Characteristic & Mean & Extreme values & Deviation \\
\hline Days to emergence & 20.08 & $16.00-27.25$ & 11.25 \\
Emergence (\%) & 49.50 & $20.00-72.50$ & 52.50 \\
\hline
\end{tabular}

Under Hungarian conditions it is possible to produce high-yielding hybrids with longer vegetation periods, thus able to make better use of the ecological potential, provided hybrids with better chilling tolerance are bred and sowing is carried out at an earlier date (Marton et al., 1999). In the suboptimal temperature range substantial differences could be demonstrated between the genotypes in the rate of germination (Marton, 1990) and in the development of the young plants (Marton, 1991; Marton and Szundy, 1997).

The relationship between temperature and green mass can be described satisfactorily by linear regression. This means that a threshold temperature above which growth becomes faster cannot be determined for the growth stage and temperature range studied (Marton et al., 1990).

Marton and Kuti (2002) elaborated a new modified joint scaling test and found that the expansion of the joint scaling test to include the [fh] parameter makes it suitable for demonstrating the effect of the level of heterozygosity of the female parent, which can be expected to be felt mainly in characters scored at emergence or in the seedling stage.

At low temperatures pathogens play an important role in the disease infection and destruction of seedlings (Záborszky et al., 2002; Szőke et al., 2007). There are significant differences between various soil samples as regards their degree of infection with pathogens. Thus the results of consecutive cold tests deviate, making it difficult or impossible to compare the data.

Other investigations were aimed at determining which of the Fusarium species existing in Hungary are widespread and the degree to which they damage germinating seeds. A study on the hybrids and parent components of an $8 \times 8$ complete diallel revealed that $F$. culmorum, $F$. poae and $F$. graminearum caused a significant reduction in the emergence of infected genotypes, while infection with $F$. oxysporum hardly decreased the survival percentage of seedlings compared to the wet control (Table 5). Infection resulted in a much higher rate of destruction in inbred lines than in their hybrids. Whereas more than $50 \%$ of hybrids survived infection, in the case of lines this ratio was $20 \times 25 \%$. Thus, the survival percentage of the hybrids compared to the average of the parent lines, i.e. the degree of heterosis, is around $240-270 \%$ in the case of strongly pathogenic species compared to $104.8 \%$ in the control. Similar results were obtained for the time to emergence and the dry matter production of the seedlings. These data confirmed the effect of adaptive heterosis. The effect of seed infection with Fusarium depends to a large extent on the temperature at 
which germination takes place. The degree of infection is also reflected to varying degrees by the characteristics studied. There is only a slight change in the time to emergence due to infection. Temperature hardly modifies the relationship between the time to emergence for infected and healthy seeds. The emergence percentage and CT value decrease significantly due to infection at low temperatures, but at higher temperatures these values improve significantly and approach the values recorded for healthy seeds. The most drastic reduction was observed for the dry matter production of emerged seedlings, which only increased slightly with an increase of temperature (Marton et al., 1988). Among the Fusarium species, infection with $F$. culmorum and $F$. graminearum caused the greatest decline in chilling tolerance (Marton et al., 2000).

Marton (1997) reported that the pathogens to be found in the germinating medium had a great influence on the results of cold tests. The extent of the cold tolerance determined in sterilised soil may be modified in infected soil as a result of the different levels of resistance to the pathogens found in the soil (Table 5). The genetic parameters estimated also depended to a considerable extent on the experimental conditions.

Table 5

Cold tolerance traits of inbred lines and their hybrids in different germinating media (Marton, 1997)

\begin{tabular}{|c|c|c|c|c|c|c|c|c|}
\hline \multirow{3}{*}{$\begin{array}{l}\text { Germinating } \\
\text { medium }\end{array}$} & \multicolumn{4}{|c|}{ Emergence } & \multirow{2}{*}{\multicolumn{2}{|c|}{$\begin{array}{l}\text { Cold tolerance } \\
\text { index }\end{array}$}} & \multirow{2}{*}{\multicolumn{2}{|c|}{$\begin{array}{l}\text { Plant height } \\
\text { (cm) }\end{array}$}} \\
\hline & \multicolumn{2}{|c|}{$\%$} & \multicolumn{2}{|c|}{ Days from planting } & & & & \\
\hline & Hybrids & Lines & Hybrids & Lines & Hybrids & Lines & Hybrids & Lines \\
\hline Sterilised soil & 86.30 & 56.10 & 19.61 & 25.87 & 4.27 & 2.29 & 9.08 & 5.07 \\
\hline Infected soil & 38.60 & 5.23 & 24.26 & 30.09 & 1.66 & 0.12 & 5.70 & 2.00 \\
\hline $\mathrm{LSD}_{5 \%}$ & 3.02 & & 0.47 & & 0.16 & & 0.38 & \\
\hline
\end{tabular}

\section{References}

Clark, B. E. (1954): Factors affecting the germination of sweet corn in low-temperature laboratory tests. N.Y. State Agr. Expt. Sta. Bul., 769, 1-24.

Herczegh, M. (1970): Some problems of cold tolerance. pp. 282-286. In: Kovács, I. (ed.), Some Methodological Achievements of the Hungarian Hybrid Maize Breeding. Akadémiai Kiadó, Budapest.

Herczegh, M. (1983): Some experimental results on the cold tolerance of maize. pp. 14-18. In: Bojanowski, J., Mlyniec, N. (eds.), Proceedings of XIIth Congress of EUCARPIA. Maize and Sorghum Section, Varna, Bulgaria.

Kovács, I. (1961): A "hidegpróba" alkalmazása a kukorica hidegtűrő képességének fokozására irányuló nemesítésben. (Application of the cold-test in our breeding programme to increase the cold tolerance of maize.) Növénytermelés, 10, 27-42.

Marton L. C. and Kuti C. (2002): Modified joint scaling test for evaluating the effect of the level of heterozygosity of the female parent. Acta Agron. Hung., 50, 185-190.

Marton, L. C. (1990): Kukorica beltenyésztett törzsek és hibridjeik hidegtürése. (Chilling tolerance of maize inbred lines and their hybrids.) PhD thesis, Martonvásár, $132 \mathrm{p}$. 
Marton, L. C. (1991): Kukorica beltenyésztett törzsek kelése és kezdeti fejlődése hőmérsékleti gradiens kamrában. II. A beltenyésztett törzsek kezdeti fejlödése. (Emergence and initial development of maize inbred lines in a thermo-gradient chamber. II. Initial development of inbred lines.) Növénytermelés, 40, 1-10.

Marton, L. C. (1997): Inheritance of cold test index of maize in sterilised and normal soil. pp. 281284. In: Bedő, Z., Sutka, J., Tischner, T., Veisz, O. (eds.), Cereal Adaptation to Low Temperature Stress in Controlled Environments. Agricultural Research Institute of the Hungarian Academy of Sciences, Martonvásár.

Marton, L. C., Berzsenyi Z., Szundy, T., Árendás, T., Bónis, P. (1999): Különböző tenyészidejü kukorica hibridek termőképességének és szemnedvességének összehasonlító értékelése. (Comparative evaluation of the yield potential and grain moisture of maize hybrids with different vegetation periods.) pp. 85-89. In: Ruzsányi, L., Lesznyák, M., Jávor, A. (eds.), Tiszántúli Mezögazdasági Tudományos Napok. Debrecen, October 28-29, 1999.

Marton, L. C., Kizmus L., Nagy, E. (2000): A fuzáriumos magfertőzés hatása a kukorica (Zea mays L.) keléskori hidegtürésére. (Effect of fusarium seed infection on the chilling tolerance of maize (Zea mays L.) at emergence.) Növénytermelés, 49, 261-272.

Marton, L. C., Kizmus, L., Herczegh, M. (1988): Cold tolerance of maize seeds infected with Fusarium species. pp. 277-286. In: Húska, J., Janda, J., Nešticky, M. (eds.), Proceedings of XIVth. Congress of EUCARPIA. Maize and Sorghum Section. Nitra, Czechoslovakia.

Marton, L. C., Szundy, T. (1997): Development of young maize plants under a suboptimal range of temperatures. Acta Agron. Hung., 45, 329-335.

Marton, L. C., Szundy, T., Kovács, I., Herczegh, M., Kizmus, L. (1990): Kukorica hidegtürési vizsgálatok Martonvásáron. (Maize cold tolerance tests in Martonvásár.) pp. 97-102. In: Kovács, I. (ed.), The Second Twenty Years of Martonvásár. Agricultural Research Institute of the Hungarian Academy of Sciences, Martonvásár.

Neptune, G. (1953): Cold tolerance studies with hybrid seed corn. Ph.D. Thesis. Michigan State Coll, $43 \mathrm{p}$.

Quang, P. D., Szundy, T. (1989): Kukorica S2 családok néhány hidegtürési tulajdonsága. (Cold tolerance traits of S2 maize families.) Növénytermelés, 1, 15-19.

Sváb, J. (1981): Biometriai módszerek a mezőgazdasági kutatásban. (Biometrical Methods in Agricultural Research.) Mezőgazdasági Kiadó, Budapest, 490 p.

Szöke, C., Árendás, T., Rácz, F., Pintér, J., Nagy, E., Marton, L. C. (2007): Correlation between maize genotypes and the stalk rot caused by maize Fusarium. Acta Agron. Hung., 55, 447452.

Szundy, T., Kovács, I. (1981a): Különböző heterozigóta szintü kukorica genotípusok és hibridjeik hidegtürésének vizsgálata. I. Heterozigóta genotípusok kelési ideje. (Study of cold tolerance in maize genotypes of various levels of heterozygosity and their hybrids. I. Time of emergence of heterozygous genotypes.) Növénytermelés, 30, 301-308.

Szundy, T., Kovács, I. (1981b): Különböző heterozigóta szintű kukorica genotípusok és hibridjeik hidegtürésének vizsgálata. II. Heterozigóta genotípusok kelési ideje. (Study of cold tolerance in maize genotypes of various levels of heterozygosity and their hybrids. II. Emergence percentage in heterozygous genotypes.) Növénytermelés, 30, 385-390.

Tatum, L. A., Zuber, M. S. (1943): Germination of maize under adverse conditions. Am. Soc. Agron., 35, 48-59.

Tischner, T., Kőszegi, B., Veisz, O. (1997): Climatic programmes used in the Martonvásár phytotron most frequently in recent years. Acta Agron. Hung., 45, 85-104.

Záborszky, S., Nagy, E., Szőke, C. (2002): Effect of seed treatment on the emergence of inbred lines of maize (Zea mays L.). Acta Agron. Hung., 50, 359-369.

Corresponding author: L. C. Marton

Phone:+36-22-569-550

E-mail: marton.csaba@agrar.mta.hu 